\author{
Stupnytska T. \\ Ph.D., Associate Professor \\ Department of Accounting and Auditing \\ E-mail: t.stupnitska@gmail.com \\ Volodina 0. \\ Assistant \\ Department of Foreigh Languages \\ E-mail: completeness7@mail.ru \\ Zhidkova K. \\ Undergraduate \\ Department of Accounting and Auditing \\ Odessa National Academy of Food Technologies \\ Kanatna str., 112, Odessa, Ukraine, 65039 \\ E-mail: kathyi822@gmail.com
}

\title{
THE DIRECTIONS OF MANAGEMENT OF THE COMMODITY DEBTS RECEIVABLE
}

The existing problems of management of debts receivable, which economic entities deal with, have been considered in the article and the mechanism of management of debts receivable has been stated and the stages of its implementation have been characterized.

Keywords: debts receivable, the problems of management, stages of development of management mechanism.

This work is licensed under a Creative Commons Attribution 4.0 International License

http://creativecommons.org/licenses/by/4.0/

Statement of the problem and its connection with important scientific and practical tasks. Debts receivable occupy a great part in current assets but at the modern stage of economic development of an enterprise, it's impossible to manage inefficiently and it causes crisis of mutual defaults payment.

The majority enterprises can't actually function properly with significant debts receivable, because they divert money from the turnover. That's why the question of the effective management of debts receivable is becoming more and more urgent as well as its timely repayment and prevention of bad debts appearance.

Forming of the aims of the research. The aim of article is studying of problems which arise in case of inefficient management of debts receivable at an enterprise, revealing of the mechanism of management of debts receivable and stages of management of debts receivable.

The analysis of the latest publications on the problem. The works of the following home scientists are devoted to investigation of the problems of analysis and management of debts receivables O. Borodkin, Ph. Butinets, O. Gorbachova, L. Lakhay, L. Prus, O. Rybalko, M.Sychova, O. Tuchak, O. Pavlovska, I. Pylypenko, M. Pushkar, I. Blanc, , I.Vlasov, S. Golov, T. Golovchenko, B. Zhnyakin, E. Ivanov, R. Kaplan, G. Kireytsev G., L. Kovalenko, V. Krasnova, V. Len, S. Maslova, L. Nosach, D. Norton, A. Rerkhacheva, E. Stoyanova. The authors consider the questions of credit policy that's why they reveal general aspects of formation of debts receivable and their estimate in their works. But there are a lot of unsolved questions, especially in the fields of development of theoretical and practical grounds of management of debts receivable of the enterprises in modern market economy of Ukraine.

Giving an account of the main results and their substantiation. Debts receivable is an integral part of current assets of the enterprise and create both positive and negative consequences for enterprise.

More than $80 \%$ of the general volume of debts receivable fall on the payments with customers for the loaded production (goods, works, services), the analysis of the economic activity of the production enterprises testifies to it. That's why debts receivable are one of the main objects of financial management of the enterprise [4, p.115-116]. In the general structure of the assets, the great part of debt receivable reduces financial stableness of the enterprise, liquidity and increases risks of financial losses. The effective policy of management of debtors allows to expand markets of commodity marketing, to attract new sellers of the production.

We can systematize the main problems of management of debt receivable, with which enterprises and organizations come across, in such a way (fig. 1). 
Absence of the precise information concerning terms of repayment of credit by enterprises-debtors
Non-developed regulations and methods of working with state debt

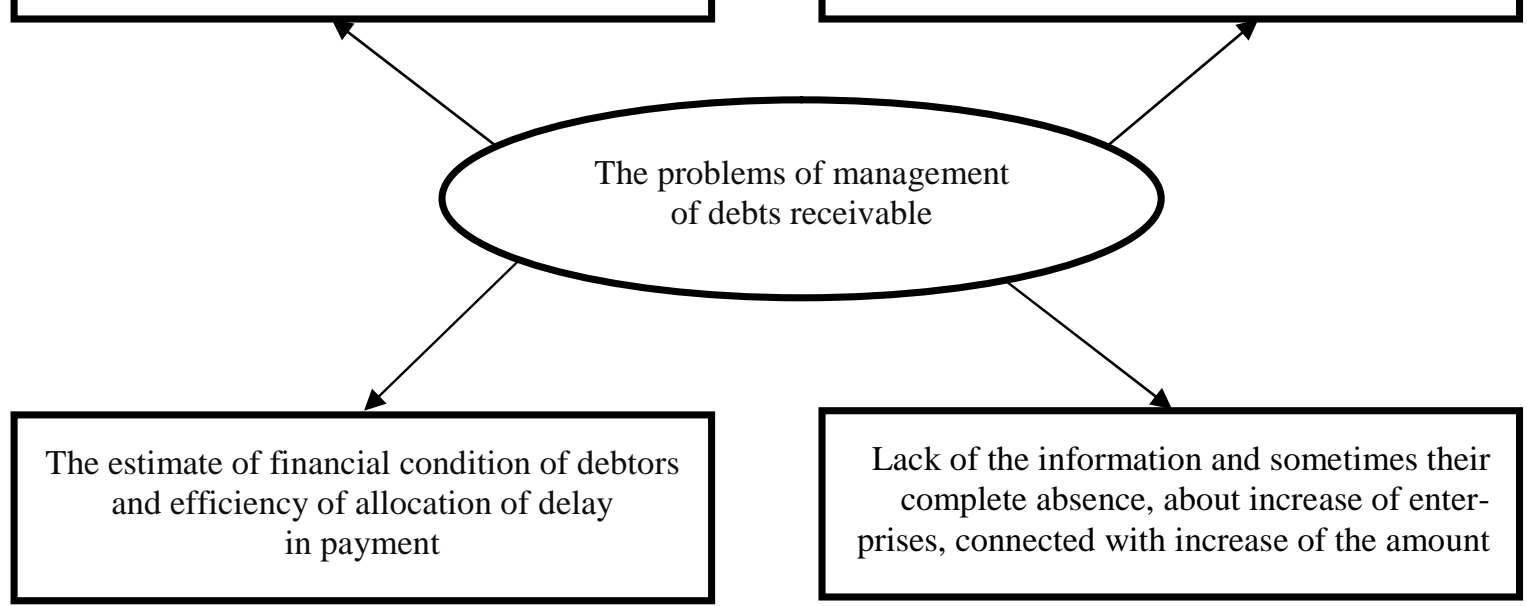

Fig. 1. The problems of management of debts receivable at the enterprises [3]

The above-mentioned problems arise in case of introducing and use of inappropriate corporate policy, marketing and management. One of such methods, according to some scientists, is determining of the methods and stages of management of debts receivable at the enterprise, which will result in improving of the financial condition of the enterprise and solving of a number of the marked problems.
Nowadays the main aim of the policy of management of debts receivable is to minimize its volume and terms of collection of debts.

For providing of the paying capacity, liquidity, a profit margin of an enterprise by creating of the efficient mechanism of debts receivable, it's necessary to fulfill the stages, shown in fig. 2 [2].

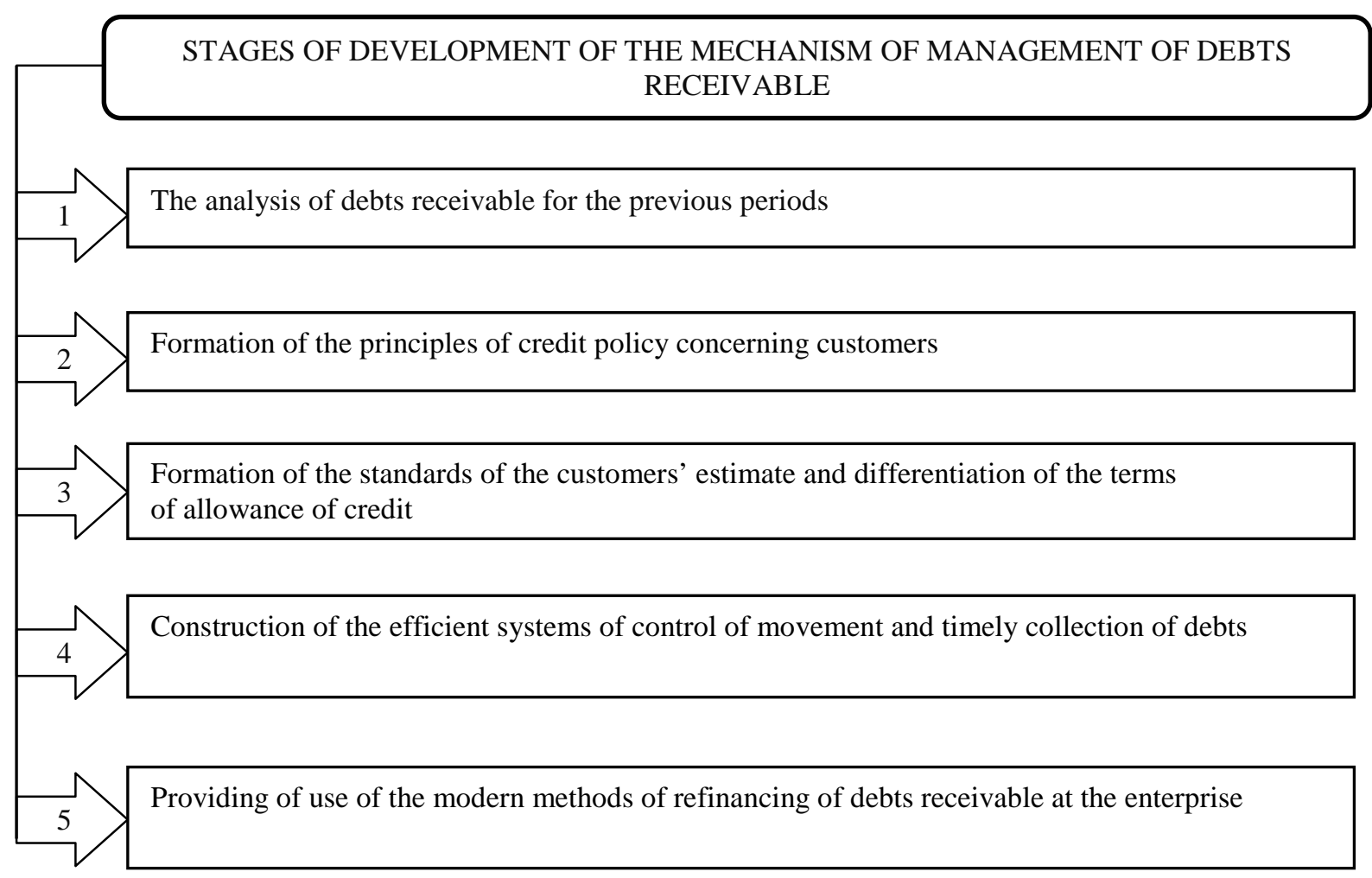

Fig. 2. Stages of development of the mechanism of debts receivable management at the enterprises [2] 
The proposed stages of development of the mechanism of debts receivable management (fig. 2) aren't exhaustive. The enterprises, depending on the specific character of their activity, can include additional stages or omit some of the above-mentioned. The content of each stage will be considered in detail. The first stage is fulfilling of the analysis of debts receivable for previous periods. The main task is an estimate of the composition and level of debts receivable of an enterprise as well as efficiency of the current assets in it. The average annual size, average term of payment and share in the structure of the revenue from operating performance are the main parameters which characterize the condition of debts receivable. It is necessary to analyze quantitative and qualitative composition of debts, coefficients of the turnover, proportions of the debts according to the sums and terms of payment, their influence on the financial results of the enterprise. The index of this probability is a term of the debt appearance as well as specific gravity of the stale debt in the total sum. The practice of the activity of economic entities testifies to the following: the larger the term of debts receivable is, the lower the probability of its payment [5, p. 114].
The great part of debts receivable stipulates reduce of the financial stability of the enterprise because it requires application of the additional sources of financing and diverts money from the turnover, that's why nowadays, in modern economic conditions, comparison of debts receivable and credit indebtedness at the enterprise is expedient. And when credit indebtedness exceeds debts receivable, the threat of financial insolvency of the enterprise is created [1, with. 47].

Formation of the principles of credit policy concerning customers, that will allow to increase sales volume, is carried out at the second stage.

The enterprises which extend commercial credit on favorable conditions for the customers, have a great demand for their production and services.

On the basis of correlation of the levels of profitability and risk of credit activity of the enterprise, the type of credit policy is determined.

Concerning relation to the customers who buy the production, there are three types of credit policy of the enterprise (fig. 3).

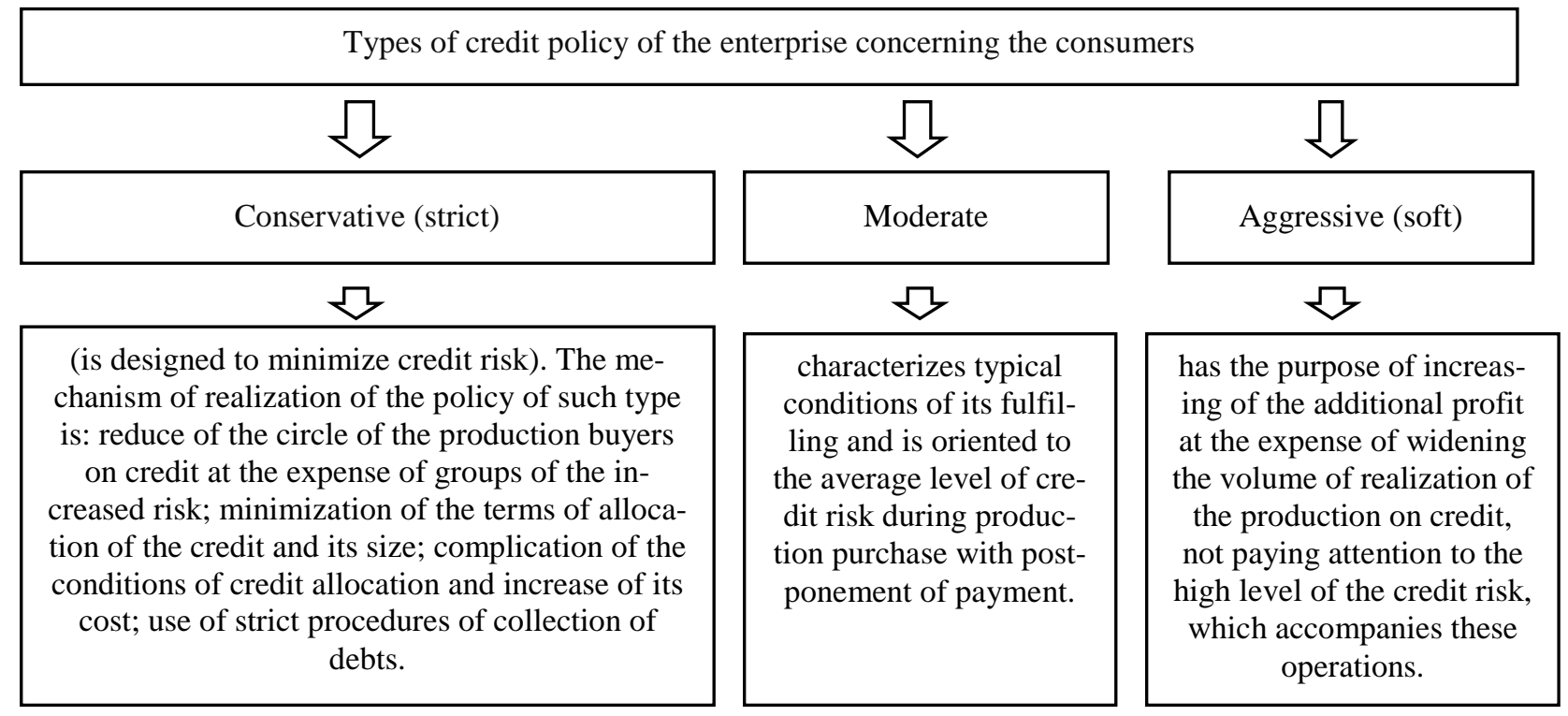

Fig. 3. Types of credit policy of the enterprises in relation to buyers [2, p. 23]

In modern conditions the credit policy is widely used in the economically developed countries. In communication with temporary hard economic conditions, the credit policy in Ukraine isn't common. That's why the aim of monetary policy of Ukraine at this moment is to decrease inflation rate (by the index of consumption prices) to the level of a simple index and keeping it at this level in a moderate-term prospect.

Realization of the third stage will allow to develop individual conditions of allocation commercial credits to different customers.

To achieve this, it's necessary to form the system of standards of the customers: estimate, which includes the following elements: determining of the characteristics system, which estimate credit solvency of sepa- rate groups of buyers, formations of the expertise of the information base of carrying out the characteristics of credit solvency of the buyers; choice of the methods of estimate of certain characteristics of credit solvency of the buyers; groupings of the buyers according to the level of credit solvency, differentiation of credit conditions in accordance with the level of credit solvency.

Conditions of crediting are a rather important factor which influences the sale volumes. They mean determining the terms of payment for certain buyers; discounts for timeliness of payment; terms of discounts validity. The enterprise must independently introduce terms of payment of the loaded protection by buyers, discounts and terms of discounts validity depending on its demands and specifics character of functioning [2, p. 24]. 
The next stage provides development of a number of measures concerning liquidation of debts receivable, the terms of which are stale, that is formation of the procedure of collection of debts receivable.

These are procedures of interaction with buyers in case of breaking of payment, the system of punishment of counterparts, who made delay in payments possible and so on.

In this case various methods, which can be classified in the following groups can be used:

- economical-financial sanctions (a fine, a penalty, a forfeit), creation of a mortgage on the property and rights on this property, stoppage of the production delivery;

- juridical-work with claims, sueing;

- psychological - reminding by phone, fax, mail, use of mass media or spreading the information among neighboring suppliers that threatens by a loss of the image of the debtor;

- physical - seizure of a debtor's property, which is done by organs of the state executive service [5, with. 117].

Appearance of the threat of alteration of debts receivable into doubtful is a signal for the enterprise that it will not only lose its profit, but also receive a damage or a loss and for its settlement it will be necessary to use own financial resources.

To avoid such situation it's necessary for the enterprise to refinance the debts receivables.

Refinancing is a transfer of debts receivables into other forms of liquid assets of the enterprise (money or high liquid funs) with the aim of acceleration of the calculations. In the world market and in Ukraine, the mechanism of returning of debts receivable which provide some methods of refinancing of debts receivable, is used, namely this are: factoring, forfaiting, accounting or bill discount.

In such a way, the following priority directions of management of debts receivable can be highlighted [6]:

\section{References}

1. Beskota , H. M. (2009). Analiz debitorskoi zaborhovanosti v systemi upravlinnia pidpryiemstvom . Derzhavatarehiony, 1, 114-117.

2. Horodianska, L. (2013). Orhanizatsiia kontroliu debitorskoi zaborhovanosti na pidpryiemstvi. Bukhhalterskyi oblik i audyt, 5, 46-53.

3. Hutsalenko , L. V., \& Slobodianiuk, I. S. (2012). Kontrol debitorskoi zaborhovanosti v upravlinni pidpryiemstvom. Zbirnyk naukovykh prats VNAU, 1, 3rd ser., 154-159.

4. Yedynak , T. S. (2009). Problemy upravlinnia debitorskoiu zaborhovanistiu pidpryiemstv v umovakh finansovo-ekonomichnoi kryzy. Derzhava ta rehiony, 3, 54-57.

5. Kozhevnikova , O. (2012). Debitorska zaborhovanist i kredytna polityka kompanii . Finansovyi rynok Ukrainy, 6, 21-25. $370-373$.

6. Kurta , N. V. (2008). Suchasni problemy upravlinnia debitorskoiu zaborhovanistiu. Derzhava ta rehiony, 6 ,

7. Maslovska, , L. T. (2010). Operatsii faktorynhu v upravlinni debitorskoiu zaborhovanistiu . Finansy Ukrainy, 6, 100-107.

8. Oborotni aktyvy za vydamy ekonomichnoi diialnosti: Ofitsiinyi sait Derzhavnoho komitetu statystyky Ukrainy .Retrieved August 17, 2017, from http://www.ukrstat.gov.ua

9. Pasinovych, I. I. (2013). Aktualni problemy analizu i upravlinnia debitorskoiu zaborhovanistiu . Ekonomika. Upravlinnia. Innovatsii, 2(10), 114-125.

10. Tuchak, O. (2012). . Upravlinnia debitorskoiu zaborhovanistiu. Balans, 92, 19-24. 


\section{Ступницкая Т.М.}

кандидат экономических наук, доцент

E-mail: t.stupnitska@gmail.com

\section{Володина Е.П.}

ассистент

кафедра иностранных языков

E-mail: completeness7@mail.ru

Жидкова К.М.

магистрант

кафедра учета и аудита

Одесская национальная академия пищевых технологий

ул. Канатная, 112, г. Одеса, Украина, 65039

E-mail: kathyi822@gmail.com

\section{НАПРАВЛЕНИЯ УПРАВЛЕНИЯ ТОВАРНОЙ ДЕБИТОРСКОЙ ЗАДОЛЖЕННОСТЬЮ}

Дебиторская задолженность занимает значительную долю в оборотных активах предприятия, но на современном этапе экономического развития предприятия не могут эффрективно управлять ею, что вызывает кризис неплатежей. Это приводит к обострению вопроса эфрфективного управления дебиторской задолженностью, своевременного ее возврата и предупреждению возникновения безнадежных долгов.

В экономической литературе рассматриваются аспекты формирования дебиторской задолженности и ее оценки, однако остается еще много нерешенных вопросов, особенно в области разработки теоретических и практических основ управления дебиторской задолженностью предприятий в современной рыночной экономике Украины.

В статье рассмотрены существующие проблемы управления дебиторской задолженностью, с которыми сталкиваются субъекты хозяйствования, также приведен механизм управления дебиторской задолженностью и охарактеризованы этапы его внедрения.

Одной из проблем предприятия, которая требует безотлагательного решения, является эффективное управление дебиторской задолженностью, что оказывает непосредственное влияние на прибыльность предприятия и определяет дисконтную и кредитную политику для покупателей, пути ускорения возврата долгов и уменьшение безнадежной задолженности, а также выбор условий продаж, обеспечивающих гарантированное поступление средств. Для улучшения фринансового состояния предприятия необходимо разработать механизм управления дебиторской задолженностью на предприятии, который позволит оптимизировать ее объемы, сроки погашения.

Ключевые слова: дебиторская задолженность, направления управления дебиторской задолженностью, механизм управления дебиторской задолженностью.

\section{Ступницька Т.М.}

кандидат економічних наук, доцент

E-mail: t.stupnitska@gmail.com

Володіна О.П. асистент

кафедра іноземних мов

E-mail: completeness7@mail.ru

Жидкова К.М.

магістрант

кафедра обліку та аудиту

Одеська національна академія харчових технологій

вул. Канатна, 112, м. Одеса, Україна, 65039

E-mail: kathyj822@gmail.com

\section{НАПРЯМИ УПРАВЛІННЯ ТОВАРНОЮ ДЕБІТОРСЬКОЮ ЗАБОРГОВАНІСТЮ}

Дебіторська заборгованість займає значну частку в оборотних активах підприємства, але на сучасному етапі економічного розвитку підприємства неспроможні ефективно управляти нею, що викликає кризу взаємонеплатежів. Це призводить до загострення питання ефективного управління 
дебіторською заборгованістю, своєчасного її повернення та попередження виникнення безнадійних боргів.

В економічній літературі розглядаються аспекти формування дебіторської заборгованості та її оцінки, проте залишається ще багато невирішених питань, особливо в галузі розробки теоретичних та практичних основ управління дебіторською заборгованістю підприємств у сучасній ринковій економіці України.

У статті розглянуто існуючі проблеми управління дебіторською заборгованістю, з якими стикаються суб'єкти господарювання, а також наведено механізм управління дебіторською заборгованістю й охарактеризовано етапи його впровадження. Однією з проблем підприємства, яка потребує негайного вирішення $є$ ефективне управління дебіторською заборгованістю, яке безпосередньо впливає на прибутковість підприємства і визначає дисконтну і кредитну політику для покупців, шляхи прискорення повернення боргів і зменшення безнадійної заборгованості, а також вибір умов продажу, що забезпечують гарантоване надходження коштів. Отже, для того щоб покращити фінансовий стан підприємства необхідно розробити механізм управління дебіторською заборгованістю на підприємстві, який дозволить оптимізувати її обсяги, терміни погашення.

Ключові слова: дебіторська заборгованість, напрями управління дебіторською заборгованістю, механізм управління дебіторською заборгованістю.

\section{Література}

1. Бескота Г.М. Аналіз дебіторської заборгованості в системі управління підприємством / Г.М. Бескота, О.Г. Лищенко // Державатарегіони. - 2009. - № 1.- С. 114-117.

2. Городянська Л. Організація контролю дебіторської заборгованості на підприємстві / Л. Городянська // Бухгалтерський облік і аудит. - 2013. - №5. - С.46-53.

3. Гуцаленко Л.В. Контроль дебіторської заборгованості в управлінні підприємством / Л.В. Гуцаленко, І.С. Слободянюк // Збірник наукових праць ВНАУ. - 2012. - №1. - Том 3.- С. 154-159.

4. Сдинак Т.С. Проблеми управління дебіторською заборгованістю підприємств в умовах фінансовоекономічної кризи / Т.С. Сдинак // Держава та регіони. - 2009. - № 3. - С. 54-57.

5. Кожевнікова О. Дебіторська заборгованість і кредитна політика компанії / О. Кожевнікова // Фінансовий ринок України. - 2012. - №6. - С.21-25.

6. Курта Н.В. Сучасні проблеми управління дебіторською заборгованістю / Н.В. Курта // Держава та регіони. - 2008. - №6. - С. 370-373.

7. Масловська, Л. Ц. Операції факторингу в управлінні дебіторською заборгованістю / Л. Ц. Масловська, І. В. Абрамова, Л. В. Недільська // Фінанси України. - 2010. - №6. - С.100-107.

8. Оборотні активи за видами економічної діяльності: Офіційний сайт Державного комітету статистики України [Електронний ресурс]. - Режим доступу: http://www.ukrstat.gov.ua

9. Пасінович I.I. Актуальні проблеми аналізу і управління дебіторською заборгованістю / I.I. Пасінович, О.М. Шевчук // Економіка. Управління. Інновації. - 2013. - № 2 (10). - С. 114-125.

10. Тучак О. Управління дебіторською заборгованістю / О. Тучак // Баланс. - 2012. - №92. - С.19-24.

Стаття надійшла 14.07.2017

Стаття прийнята до друку 28.07.2017

Доступно в мережі Internet 30.09.2017 